\title{
Harmonia axyridis: a threat to Brazilian Coccinellidae? ${ }^{1}$
}

\author{
Camila B. C. Martins², Lúcia M. Almeida3 ${ }^{3}$ Regina C. Zonta-de-Carvalho ${ }^{4}$, Camila F. Castro² \\ \& Rosylaine A. Pereira ${ }^{2}$
}

${ }^{1}$ Contribution number 1792 of the Department of Zoology, Universidade Federal do Paraná, Brazil.

${ }^{2}$ Laboratório de Sistemática e Bioecologia de Coleoptera (Insecta), Departamento de Zoologia, Universidade Federal do Paraná, Caixa Postal 19030, Curitiba, Brazil. Fellowship CAPES. camibcm@yahoo.com

${ }^{3}$ Fellowship CNPq lalmeida@ufpr.br

${ }^{4}$ Centro de Diagnóstico Marcos Enrietti - SEAB/PR, Curitiba, Brazil.

\begin{abstract}
Harmonia axyridis: a threat to Brazilian Coccinellidae? Harmonia axyridis (Pallas) (Coleoptera, Coccinellidae) is a polyphagous Asian species, well-known as a classical biological control agent of aphids around the world, introduced probably accidentally in Brazil, sampled for the first time in 2002. It is an important intraguild predator, competing for food with native coccinellids. It was studied $H$. axyridis alimentary sources and host plants, its abundance compared with native and established species, the influence of abiotic factors and the seasons over the abundance of $H$. axyridis throughout one year, and discussed the mechanisms which influence the displacement of species. Harmonia axyridis was found in 38 plant species, among them 20 were new records, feeding on 20 aphid species, eight of them new alimentary records. Between 2006/2007, eight Coccinellidae species were collected and $H$. axyridis was the most abundant (91.23\%). Harmonia axyridis peak of abundance occurred in August and September 2007, probably influenced by the temperature and food availability. From 1999 to 2007 a reduction and variation in the diversity of collected species of Coccinellidae were observed with the predominance of $H$. axyridis, which may indicate their displacement.
\end{abstract}

KEYWORDS. Aphididae; intraguild predation; invasive species; native species.

RESUMO. Harmonia axyridis: uma ameaça aos Coccinellidae brasileiros? Harmonia axyridis (Pallas) (Coleoptera, Coccinellidae) é uma espécie asiática, polífaga e reconhecida como agente de controle biológico de afídeos pelo mundo, provavelmente introduzida acidentalmente no Brasil, coletada pela primeira vez em 2002. É um importante predador intraguilda, pois compete por alimento com as espécies nativas de coccinelídeos. Foram estudadas as fontes alimentares de $H$. axyridis e suas plantas hospedeiras, sua abundância em relação às espécies nativas e estabelecidas, a influência dos fatores abióticos e as estações do ano sobre sua abundância durante um ano e discutidos os mecanismos que influenciam no deslocamento das espécies nativas de Coccinellidae. Além disso, foi testada a influência dos fatores abióticos e as estações do ano sobre sua abundância durante um ano. Harmonia axyridis foi encontrada em 38 espécies de plantas, sendo 20 delas novos registros, alimentando-se de 20 espécies de afídeos, oito novos registros alimentares. Entre os anos de 2006/2007, oito espécies de Coccinellidae foram coletadas e H. axyridis foi a mais abundante (91,23\%). O pico de abundância de $H$. axyridis ocorreu em agosto e setembro de 2007, provavelmente influenciado pela temperatura e disponibilidade de alimento. Entre 1999 e 2007, foram observadas a redução e variação na diversidade de espécies de Coccinellidae coletadas, com a predominância de H. axyridis, o que pode indicar o desalojamento destas espécies.

PALAVRAS-CHAVE. Aphididae; espécie invasora; espécie nativa; predação intraguilda.

Harmonia axyridis (Pallas, 1773) is an Asiatic polyphagous coccinellid. Its original distribution extended from the southern of Siberia (Altai Mountains) to Manchuria, Korea, Japan and China (Tan 1946). H. axyridis has been used successfully as a biological control agent of aphids around the world (Koch 2003). However, it may cause impacts on non-target arthropods through intraguild predation and losses in grape and wine production (Koch \& Galvan 2008).

In the United States, the multicolored Asian lady beetle was introduced as a biological control agent at different periods of time: California in 1916, 1964 and 1965; Washington between 1978-1982; New Scotland, Connecticut, Georgia, Louisiana, Maryland, Washington D.C., Delaware, Maine, Mississippi, Ohio, Pennsylvania and North Carolina between 1978-1981 (Gordon 1985). Since the establishment of the first population, which occurred only in 1988 (Chapin \& Brou 1991), there has been successful control for some aphid species, such as Aphis spiraecola Patch, 1914 on apple orchards (Brown \& Miller 1998).

Harmonia axyridis was also introduced as a biological control agent in several European countries (Brown et al. 2008). In Belgium, $H$. axyridis has been used for biological control since 1997. However, after 2001, when the first reports of $H$. axyridis were done in the wild, in Ghent, the number of observations increased in cities, anthropogenic sites, and in (semi-)natural habitats such as forests and meadows (Adriaens et al. 2003). According to Brown et al. (2008), "over a very short time period H. axyridis is likely to become one of the most widely distributed coccinellids in Europe".

In the late 1990's, H. axyridis was first introduced in South 
America in Mendoza Province, Argentina, to control aphids of peach culture (Saini 2004). In 2002, it was first detected in Curitiba, Paraná State, Brazil, probably accidently introduced, feeding on Tinocallis kahawaluokalani (Kirkaldy, 1907), (Drepanosiphinae) in crape myrtle, Lagerstroemia indica L. (Lythraceae) and in young Pinus spp. (Pinaceae), feeding on Cinara atlantica (Wilson, 1919) and Cinara pinivora (Wilson, 1919) (Lachninae) (Almeida \& Silva 2002). Recently, occasional appearances of $H$. axyridis were reported in Chile (González 2006) and Peru (González \& Vandenberg 2007).

About the establishment of $H$. axyridis in the South American continent, Koch et al. (2006) suggest that large areas are likely to become adequate habitats because of the similar climatic conditions with its native countries and the same kind of biomes. Also the prey availability must not be a limiting factor to its establishment in the region, as it is capable to disseminate by flying and also by other means linked to human activities. According to the "Climex" distribution model, H. axyridis has the potential to establish in several countries in Latin America. Besides Brazil and Argentina, possible localities for its occupations are Paraguay, Uruguay, Chile, Venezuela, Colombia, Ecuador, Peru and Bolivia (Poutsma et al. 2008).

As an invasive species, $H$. axyridis may cause negative impacts, including the displacement of natural native enemies and the suppression or extinction of non-target prey species (Elliot et al. 1996). In the United States, this species was observed competing with Coleomegilla maculata DeGeer, 1775 , an important native predator that feeds on many aphid species, as well as other arthropods and insect eggs (Hodek \& Honek 1996). In Brazil, H. axyridis has been monitored in the field and may compete with Cycloneda sanguinea (Linnaeus, 1763), the main aphidophagous native species.

Considering the worldwide status and effects of $H$. axyridis, it is of great importance to know its behavioral characteristics in Brazil, and determine the dominant species in a Coccinellidae community. This study focuses on $H$. axyridis alimentary sources and host plants and on changes in the abundance and diversity of native and established ladybird species before and after the introduction of $H$. axyridis in Curitiba, Brazil. Furthermore, an investigation was carried out, testing the influence of abiotic factors and the temporal variation (season) on the abundance of $H$. axyridis throughout one year (2006/ 2007).

\section{MATERIALAND METHODS}

Harmonia axyridis alimentary sources and host plants. These relations were based on the co-occurrence of $H$. axyridis (as egg, larvae and pupae) and aphids on the same plant. From August 2005 to November 2007 plant species were examined and sampled with aphids and adults of $H$. axyridis. Every week, samplings were done manually with a beating tray and a trimmer, in Curitiba and surrounding cities, like Araucaria [Latitude 25 35'35' S; Longitude 49 24'37' W]; and Quatro Barras [Latitude $25^{\circ} 23^{\prime} 30^{\prime \prime} \mathrm{S}$; Longitude $49^{\circ} 07^{\prime} 30^{\prime \prime} \mathrm{W}$ ]. The ladybirds were brought to the laboratory and included in Coleção de Entomologia Pe. J. S. Moure of the Department Zoology, (UFPR). Aphids were fixed in ethanol 70\%, mounted on microscope slides for identification and included in the insect collection of the Centro de Diagnóstico Marcos Enrietti, in Curitiba.

Sampling of the Coccinellidae community before and after the report of Harmonia axyridis. Between October/1999 September/2000 and September/2001 - August/2002 Coccinellidae exploratory samplings were done in an approximately $5.300 \mathrm{~m}^{2}$ area located in the Capão do Tigre field, Curitiba, State of Paraná (2526'50" - 25'27'33'"S and 49 $14^{\prime} 16^{\prime \prime}$ - 49 $14^{\prime} 33^{\prime \prime} \mathrm{W}$ ) and between October/2006 and September/2007, new samplings were also done in this area. Capão do Tigre has 15.24 ha and it is located at $900 \mathrm{~m}$ above sea level. The climate of the region is subtropical mesothermic humid with cool summers, frequent frosts during winter and no dry season, classified as Cfb according to Köppen's classification (Köppen 1948). The annual average temperatures in hot and cold months are below $22^{\circ} \mathrm{C}$ and $18^{\circ} \mathrm{C}$, respectively, and the annual average temperature is $17^{\circ} \mathrm{C}$. The annual averages of relative atmospheric humidity and precipitation are $85 \%$ and 1,300 to $1,500 \mathrm{~mm}$, respectively. The study area is characterized by the presence of secondary forest with predominance of ferns in areas previously occupied by Araucaria angustifolia (Bertol.) O. Kuntze (Maack 1981), though Pinus sp. and Baccharis spp. currently predominate in the area.

Both first (1999/2002) and second sampling periods (2006/ 2007) were done weekly, for one-hour. Every plant (mainly Pinus spp. and Baccharis spp.) of the area was examined and coccinellids were sampled manually. From 1999 to 2002, samplings aimed to detect only the local coccinellid species present in the area. However on the second period, plants, aphids and coccinellids were collected. The occurrence and abundance of species in the area during both periods were compared, and possible interferences in the local fauna, influenced by the introduction of $H$. axyridis, were analyzed.

Statistical analysis. Data about temperature, precipitation and relative humidity, from 2006/2007, were obtained daily by Instituto Tecnológico (SIMEPAR-UFPR), in Curitiba.

To test the effects of abiotic factors on patterns of abundance variation of $H$. axyridis a simple linear regression analysis was used, using mensal average abundance and average of abiotic factors. The Kolmorogov-Smirnov test was done to ascertain the normality of the data.

To test for temporal variation in abundance of $H$. axyridis between seasons a one-way ANOVA were used with season and abundance as fixed factors. A posteriori test (tukey HSD) was done to evaluate which groups differ. All statistical analysis was performed with Statistica 5.5 (StatSoft Inc. 2000).

The period that composes seasons in 2006 and 2007 were considered as follows: spring (September 23 - December 20), summer (December 21 - March 19), fall (March 20 - June 20) and winter (June 21 - September 22). 


\section{RESULTS}

Harmonia axyridis alimentary sources and host plants. From August 2005 to November 2007, H. axyridis was sampled feeding on 20 aphid species and on 38 plant species of 18 families (Table I). There were eight new records of aphid used as prey: Aphis coreopsidis (Thomas, 1878), Brachycaudus helichrysi (Kaltenbach, 1843), Essigella californica (Essig, 1909), Hyperomyzus lactucae (Linnaeus, 1758), Macrosiphoniella yomogifoliae (Shinji, 1924), Neophyllaphis podocarpini Carrillo, 1980, Neotoxoptera formosana (Takahashi, 1921) and Uroleucom sonchi (Linnaeus, 1767) and one Psyllidae, Triozoida sp. in Psidium guajava L. (Table I).

During the entire experimental period adults, eggs and larvae of $H$. axyridis co-occurred, except in Chrysanthemum leucanthemum L., Duranta repens L., Foeniculum vulgare Miller, Hipochoeris radicata L., Psidium guajava L., Rosa sp., Schefflera arboricola (Hayata) Merr., Tabebuia sp. and Tipuana tipu (Benth.) Kuntze, in which only adults were observed.

All life stages of $H$. axyridis were found on plants with some kind of prey, except on Cucurbita pepo var. melopepo, Cucumis sativus L., Abelmoschus esculentus (L.) Moench, Cucumis melo L., Zea mays L., Odontonema strictum Kuntze, Tabebuia chrysotricha (Mart. Ex Dc.) Standl and Sechium edule Swartz (Table II).

The data obtained with this study (Table I) and in the literature (Koch et al. 2006) sum up approximately 77 prey species, found on 83 plants species in 35 families, of which Asteraceae, Pinaceae, Fabaceae and Rosaceae have the largest numbers of tritrophic relations (H. axyridis x prey x host) (Table I).

Sampling of the Coccinellidae community before and after Harmonia axyridis introduction. After $H$. axyridis introduction, five species were not found anymore and there was a change in the dominant species in the Capão do Tigre area (Table III).

Between 1999/2002, the following Coccinellidae species were sampled: Cycloneda pulchella (Klug, 1829), Cycloneda sanguinea (L., 1763), Curinus coeruleus (Mulsant, 1850), Eriopsis connexa (Germar, 1824), H. axyridis, Hippodamia convergens Guérin-Méneville, 1842, Hyperaspis festiva Mulsant, 1850, Scymnus sp., Olla v-nigrum (Mulsant, 1866), Psyllobora gratiosa Mader, 1958 and Rodolia cardinalis (Mulsant, 1850). Nine species of Coccinellidae among 539 specimens were recorded between October/1999 - September/ 2000, before the introduction of $H$. axyridis: $C$. sanguinea (58\%); H. convergens (20.59\%); Scymnus sp. (9.65\%); P. gratiosa (4.82\%); E. connexa $(2.97 \%)$; C. pulchella $(1.85 \%)$; O. v-nigrum (1.48\%); H. festiva $(0.18 \%)$; R. cardinalis $(0.37 \%)$.

Between September 2001 and August 2002, 586 specimens of eight species were found and $C$. sanguinea was the dominant species (84.98\%), followed by H. axyridis $(10.24 \%)$; O. v-nigrum (1.71\%); H. convergens (10.24\%), E. connexa $(0.85 \%)$; C. coeruleus $(0.68 \%)$; Scymnus sp. $(0.34 \%)$ and Cycloneda ocelligera (Crotch, 1874) (0.17\%) (Table III).

Between October 2006 and September 2007, 1,038 ladybirds

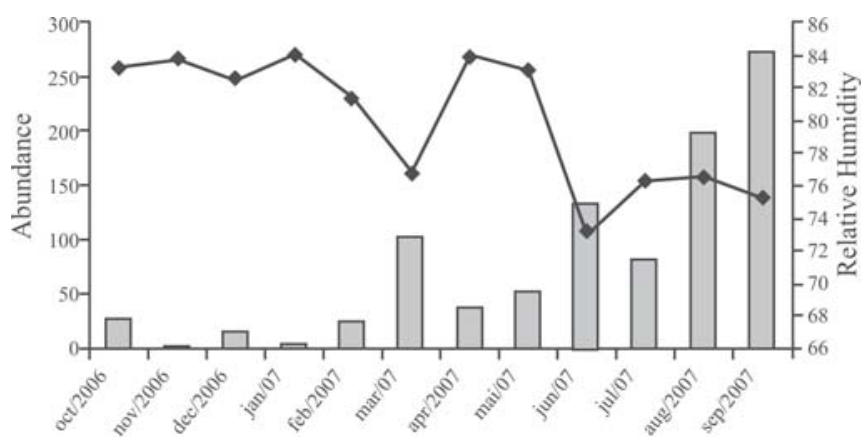

Fig. 1. Relation between fluctuation of Harmonia axyridis (Pallas) and relative humidity in the Capão do Tigre, Curitiba, Paraná, Brazil. Period - October, 2006 to September, 2007.

of eight species were collected. In this period, $H$. axyridis was more abundant $(91.23 \%)$ than all native and/or established species. These species were: O. v-nigrum (3.08\%), C. sanguinea $(2.02 \%)$, Coccidophilus citricola Bréthes, 1905 (1.83\%), Scymnus sp. (0.96\%), H. convergens (0.48\%), C. pulchella $(0.29 \%)$ and C. coeruleus $(0.10 \%)$ (Table III, IV). Harmonia axyridis, O. v-nigrum, C. sanguinea, C. citricola, Scymnus sp. and H. convergens were collected in Pinus spp. with the aphids: $C$. atlantica, C. pinivora and E. californica. Harmonia axyridis, C. pulchella, C. coeruleus, C. sanguinea and $H$. convergens were collected in Baccharis sp.1 and sp.2 with A. spiraecola Patch, 1914, and in Baccharis sp.1 with unidentified scales (Coccidae). In Baccharis sp.3, only $H$. axyridis and scales were observed.

Comparison of monthly abundance of Harmonia axyridis. The mean abundance of $H$. axyrids was $23.4 \pm 32.49$ individuals (mean $\pm \mathrm{sd}$ ), which indicates an aggregated distribution trough seasons. The highest abundance of $H$. axyridis occurred between August and September 2007, with a decrease in November, December 2006 and January 2007 and a small increase in March and June 2007 (Fig. 1).

Since all life stages were found throughout the period of 2006/2007, H. axyridis was considered multivoltine in Curitiba. The linear regression analysis showed that the abundance of H. axyridis is significantly related to the temperatures $\left(\mathrm{F}_{2,9}=\right.$ $14,978 \mathrm{p}<0.00137, \mathrm{R}^{2}=0.7176$; values of mean and maximum temperatures $\mathrm{p}=0.0004, \mathrm{p}=0.0006$, respectively). The ANOVA revealed that the abundance of $H$. axyridis per season was significantly different $\left(\mathrm{F}_{3,36}=4.7950, \mathrm{p}=0.0065\right)$ with the number of $H$. axyridis captured during the winter significantly higher when compared with the fall $(\mathrm{p}=0.03915)$ and the spring $(\mathrm{p}=0.01027)$.

\section{DISCUSSION}

Harmonia. axyridis alimentary sources and host plants. Hodek \& Honek (1996) indicated that the observation of mutual occurrence of coccinellids and prey insects in a given plant does not necessarily indicate a prey-predator relationship. However, $H$. axyridis lays eggs before or in the highest 
Table I. Host plants and prey associated with Harmonia axyridis. Complementing Koch et al. (2006). * New tritrophic relation; + New host plant registered; ${ }^{\circ}$ New prey registered; E Eggs; L Larvae; P Pupae; A Adult;

\begin{tabular}{|c|c|c|c|}
\hline Host plants - Families & obs. & Preys & Life stages \\
\hline \multicolumn{4}{|l|}{ Apiaceae } \\
\hline Foeniculum vulgare Miller & $*+$ & Aphis fabae Scopoli & A \\
\hline \multicolumn{4}{|l|}{ Araliaceae } \\
\hline Schefflera arboricola (Hayata) Merr. & $*+$ & Aphis sp. & A \\
\hline \multicolumn{4}{|l|}{ Asteraceae } \\
\hline Baccharis sp.1 & $*+$ & Aphis spiraecola Patch; Coccidae & $\mathrm{E}, \mathrm{L}, \mathrm{P}, \mathrm{A}$ \\
\hline Baccharis sp. 2 & $*+$ & Aphis spiraecola Patch & A \\
\hline \multirow[t]{2}{*}{ Baccharis sp. 3} & + & Coccidae & $\mathrm{L}, \mathrm{A}$ \\
\hline & $*+{ }^{\circ}$ & Aphis coreopsidis (Thomas); & $\mathrm{L}, \mathrm{A}$ \\
\hline \multirow[t]{2}{*}{ Bidens pilosa $\mathrm{L}$. } & $*+{ }^{\circ}$ & Uroleucon sonchi (Linnaeus); & A \\
\hline & $*+{ }^{\circ}$ & Hyperomyzus lactucae (Linnaeus) & A \\
\hline Bidens sulphurea (Cav.) Sch. Bip. & $*+{ }^{\circ}$ & Macrosiphoniella yomogifoliae (Shinji) & $\mathrm{L}, \mathrm{A}$ \\
\hline Chrysanthemum leucanthemum $\mathrm{L}$. & $*+{ }^{\circ}$ & Brachycaudus helichrysi (Kaltenbach) & A \\
\hline Helianthus annuus L. & $*+$ & Aphis fabae Scopoli & $\mathrm{E}, \mathrm{A}$ \\
\hline Hipochoeris radicata $\mathrm{L}$. & $*+$ & Uroleucon ambrosiae (Thomas) & A \\
\hline \multirow{2}{*}{ Lactuca sativa $\mathrm{L}$. } & & Uroleucon ambrosiae (Thomas); & $\mathrm{L}, \mathrm{A}$ \\
\hline & $*+{ }^{\circ}$ & Uroleucom sonchi (Linnaeus) & $\mathrm{L}, \mathrm{A}$ \\
\hline Sonchus oleraceus L. & $*+{ }^{\circ}$ & Uroleucom sonchi (Linnaeus) & $\mathrm{E}, \mathrm{L}, \mathrm{P}, \mathrm{A}$ \\
\hline \multicolumn{4}{|l|}{ Bignoniaceae } \\
\hline Tabebuia sp. & $*+$ & Nimphs of Psyllidae & A \\
\hline \multicolumn{4}{|l|}{ Brassicaceae } \\
\hline Brassica oleracea L. var. italica & $*+$ & Myzus persicae (Sulzer);Lipaphis erysimi (Kaltenbach) & $\mathrm{P}$ \\
\hline Brassica oleraceae L. var. capitata & $*+$ & Brevicoryne brassicae (Linnaeus) & $\mathrm{L}$ \\
\hline Brassica oleraceae L. var. leucocephala & $*+$ & Brevicoryne brassicae (Linnaeus) & $\mathrm{E}, \mathrm{A}$ \\
\hline Spartium junceum L. & $*+$ & Aphis craccivora $($ Koch $)$ & $\mathrm{E}, \mathrm{A}$ \\
\hline \multicolumn{4}{|l|}{ Fabaceae } \\
\hline Tipuana tipu (Benth.)Kuntze & $*+$ & Psyllidae & A \\
\hline \multicolumn{4}{|l|}{ Liliaceae } \\
\hline Allium schoenoprasum L. & $*+{ }^{\circ}$ & Neotoxoptera formosana (Takahashi) & $\mathrm{E}, \mathrm{L}, \mathrm{A}$ \\
\hline \multicolumn{4}{|l|}{ Lythraceae } \\
\hline Lafoensia pacari $\mathrm{L}$. & $*+$ & Psyllidae & $\mathrm{E}, \mathrm{L}, \mathrm{P}, \mathrm{A}$ \\
\hline Lagerstroemia indica $\mathrm{L}$. & $*$ & Toxoptera aurantii (Boyer de Fonscolombe) & $\mathrm{E}, \mathrm{P}, \mathrm{A}$ \\
\hline \multicolumn{4}{|l|}{ Malvaceae } \\
\hline Hibiscus rosa sinensis L. & $*+$ & Nimphs of Toxoptera sp.; Aphis sp. & $\mathrm{E}, \mathrm{A}$ \\
\hline \multicolumn{4}{|l|}{ Myrtaceae } \\
\hline Myrciaria cauliflora (Mart.) O. Berg & + & Larvae of Curculionidae & $\mathrm{L}, \mathrm{P}, \mathrm{A}$ \\
\hline Psidium guajava L. & $*+{ }^{\circ}$ & Triozoida sp. & A \\
\hline \multicolumn{4}{|l|}{ Pinaceae } \\
\hline Pinus sp. & $*$ o & $\begin{array}{l}\text { Cinara pinivora (Wilson); Cinara atlantica (Wilson); } \\
\text { Essigella californica (Essig) }\end{array}$ & $\mathrm{E}, \mathrm{L}, \mathrm{P}, \mathrm{A}$ \\
\hline \multicolumn{4}{|l|}{ Podocarpaceae } \\
\hline Podocarpus sp. & o & Neophyllaphis podocarpini Carrilo & $\mathrm{E}, \mathrm{A}$ \\
\hline \multicolumn{4}{|l|}{ Rosaceae } \\
\hline Rosa sp. & & Macrosiphum rosae (Linnaeus) & $\mathrm{A}$ \\
\hline \multicolumn{4}{|l|}{ Rutaceae } \\
\hline Citrus limon L. & & Toxoptera citricida (Kirkaldy) & $\mathrm{E}, \mathrm{L}, \mathrm{P}, \mathrm{A}$ \\
\hline Citrus sinensis L. & & Aphididae & $\mathrm{E}, \mathrm{L}, \mathrm{P}, \mathrm{A}$ \\
\hline Citrus reticulata $\mathrm{L}$. & & Aphididae & $\mathrm{E}, \mathrm{L}, \mathrm{P}, \mathrm{A}$ \\
\hline \multicolumn{4}{|l|}{ Verbenaceae } \\
\hline Duranta repens L. & + & Coccidae & A \\
\hline
\end{tabular}

population level of aphids on a plant (Hironori \& Katsuhiro 1997; Osawa 2000). Consequently, the presence of $H$. axyridis eggs, larvae and pupae in plants with aphids was considered an indication of these coccinellids' development, establishing a prey-predator relation, as they co-inhabit the same host.

In Curitiba, $H$. axyridis was collected together with several prey species (aphids, scales, psyllids) that it may use as food sources, but in some plants there were no alimentary sources available (Table II). However, since larvae and pupae were present in these hosts, some kind of food source has been supposedly there.

Only adults were collected and no food sources were found 
Table II. Correlation between the life stages of H. axyridis and its host plants found without alimentary sources, collected in Curitiba, Brazil. Period - August 2005 to November 2007.

\begin{tabular}{|c|c|c|c|c|}
\hline \multicolumn{4}{|c|}{ Coccinellidae } & \multirow{2}{*}{ Host Plant } \\
\hline egg & larvae & pupae & adult & \\
\hline & $\mathrm{X}$ & & & Cucurbita pepo var. melopepo - Cucurbitaceae \\
\hline & $\mathrm{x}$ & & $\mathrm{x}$ & Cucumis sativus L. - Cucurbitaceae \\
\hline & $\mathrm{x}$ & & $\mathrm{x}$ & Abelmoschus esculentus (L.) Moench - Malvaceae \\
\hline & $\mathrm{x}$ & & $\mathrm{x}$ & Cucumis melo L. - Cucurbitaceae \\
\hline & & & $\mathrm{x}$ & Zea mays L. - Poaceae \\
\hline & & & $\mathrm{x}$ & Odontonema strictum Kuntze - Acanthaceae \\
\hline \multirow[t]{2}{*}{$\mathrm{x}$} & & $\mathrm{x}$ & $\mathrm{x}$ & Tabebuia chrysotricha (Mart. Ex Dc.) Standl. - Bignoniaceae \\
\hline & $\mathrm{x}$ & $\mathrm{x}$ & & Sechium edule Swartz - Cucurbitaceae \\
\hline
\end{tabular}

in Zea mays L.. Nevertheless, $H$. axyridis has already been found in corn, regularly laying eggs and feeding on Rhopalosiphum maidis (Fitch, 1856) (Musser \& Shelton 2003). Likewise, Aphis gossypii Glover, 1877, has already been captured in Tabebuia chrysotricha (Mart. ex DC.) Standl. (Peronti \& Souza-Silva 2002), Sechium edule Swartz (Neupane et al. 2006), Cucumis sativus L. (Steenis \& El-Khawass 1995), Cucumis melo L. (Kingler et al. 1998) and Abelmoschus esculentus (L.) Moench (Leite et al. 2007).

Harmonia axyridis was present even when the quantity of aphids was very low in Capão do Tigre area, meaning that it may consumed other food sources. Aphids' replacement by other plant origin products, such as nectar and pollen, may work as alternative food when preys are scarce, reducing mortality and maintaining the Coccinellidae population abundant (Hodek \& Honek 1996).

In the lack of aphids $H$. axyridis may feed on different kinds of prey such as on Tetranichidae (Lucas et al. 1997), Psyllidae (Michaud 2004), Coccoidea (McClure 1986), Curculionidae (Stuart et al. 2002) and Lepidoptera (Koch et al. 2003), plant material, damaged fruits (Koch et al. 2004), nectar and pollen (LaMana \& Miller 1996), which allows a complete development for H. axyridis (Berkvens et al. 2008).

Comparison of monthly abundance of Harmonia axyridis. The linear regression analysis showed that the abundance of $H$. axyridis is related to the temperature. This relationship could be caused by the dependence of $H$. axyridis development on the temperature.

The development of $H$. axyridis immature stages occurs at temperatures that range between $13.2^{\circ} \mathrm{C}$ and $23.3^{\circ} \mathrm{C}$. In short days when mean temperatures are lower than $12^{\circ} \mathrm{C}, H$. axyridis does not reproduce, and that at temperatures above $23^{\circ} \mathrm{C}$, it changes or prevents eggs incubation and larval development (Ongagna et al. 1993). Under laboratory conditions, $H$. axyridis completed its life cycle in 20 days at a temperature that ranged from $20.2^{\circ} \mathrm{C}$ to $25.8^{\circ} \mathrm{C}$ (Saini 2004). Throughout the sampling period, the mean temperature reached $22.9^{\circ} \mathrm{C}$, indicating that the south region of Brazil allows $H$. axyridis development.

Harmonia axyridis has at least three generations per year in Curitiba, two in Oregon, United States (LaMana \& Miller 1996) and in Antibes, France (Ongagna et al. 1993), four generations in Athens, Greece (Katsoyannos et al. 1997), and in Japan, its native region, two to three generations (Osawa 1993). The number of generations in Brazil may be higher in locations where temperatures are milder during the winter.

In addition to climatic factors, Coccinellidae development also depends on food quality (Dixon 2000). Osawa (2000), in Japan, concluded that $H$. axyridis life cycle overlaps with the aphids', and that seasonal changes in the number of specimens sampled varied according to the number of aphids available. In Santa Maria (RS), the abundance of Coccinellidae sampled in Citrus spp. also varied according to food availability in the field (Arioli \& Link 1987). Therefore, in Curitiba, the winter may have provided a greater quantity and quality of food if compared with the other seasons, explaining the high number of individuals captured in this season. There was a great mean deviation in the abundance of $H$. axyridis collected per week, which is probably related to the availability of alimentary sources in the area.

Between 2006/2007, H. axyridis was captured in plants infested with four aphid species, especially $C$. atlantica and C. pinivora, and one species of Coccidae. In southern Brazil, the highest level of Cinara spp. population occurs in cold months, when mean temperatures are approximately $15^{\circ} \mathrm{C}$ (Cardoso \& Lazzari 2003). This aphid might have been $H$. axyridis main prey during the winter. On the other hand, A. spiraecola found on Baccharis spp. (Table I) develops in temperatures between $20^{\circ} \mathrm{C}$ and $30^{\circ} \mathrm{C}$ (Wang \& Tsai 2000) and might have been $H$. axyridis food source in spring and summer.

Currently occurring species of Coccinellidae in the Capão do Tigre area and Harmonia axyridis introduction in Brazil. Coccinellidae has not been systematic sampled in Brazil and the few systematic samplings are composed by an annual inventory of Coleoptera in Vila Velha, State of Paraná, in which Coccinellidae was the eighth most sampled family (Ganho \& Marinoni 2005); and samples made in the city of Santa Maria, State of Rio Grande do Sul (RS), in 1985 and 1986, in which 23 species were captured in orchards of Citrus spp. (Arioli \& Link 1987).

In Capão do Tigre, 13 Coccinellidae species have been sampled since 1999 (Table III) and five (P. gratiosa, E. connexa, 
Table III. Relation between species and abundance of Coccinellidae specimens in different periods of sampling: 1999-2002 and 2006-2007, in Capão do Tigre, Curitiba, Paraná, Brazil.

\begin{tabular}{|c|c|c|c|c|c|c|}
\hline Coccinellidae species & Sep.99 - Sep.00 & Rel. Freq. & Sep.01 - Aug.02 & Rel. Freq. & Oct.06 - Sep.07 & Rel. Freq. \\
\hline Harmonia axyridis & 0 & & 60 & $10.24 \%$ & 947 & $91.23 \%$ \\
\hline Olla v-nigrum & 8 & $1.48 \%$ & 10 & $1.71 \%$ & 32 & $3.08 \%$ \\
\hline Cycloneda sanguinea & 313 & $58.07 \%$ & 498 & $84.98 \%$ & 21 & $2.02 \%$ \\
\hline Coccidophilus citricola & 0 & & 0 & & 19 & $1.83 \%$ \\
\hline Scymnus sp. & 52 & $9.65 \%$ & 2 & $0.34 \%$ & 10 & $0.96 \%$ \\
\hline Hippodamia convergens & 111 & $20.59 \%$ & 6 & $1.02 \%$ & 5 & $0.48 \%$ \\
\hline Cycloneda pulchella & 10 & $1.85 \%$ & 0 & & 3 & $0.29 \%$ \\
\hline Curinus coeruleus & 0 & & 4 & $0.68 \%$ & 1 & $0.09 \%$ \\
\hline Psyllobora gratiosa & 26 & $4.82 \%$ & 0 & & 0 & \\
\hline Eriopis connexa & 16 & $2.97 \%$ & 5 & $0.85 \%$ & 0 & \\
\hline Rodolia cardinalis & 2 & $0.37 \%$ & 0 & & 0 & \\
\hline Hyperaspis festiva & 1 & $0.18 \%$ & 0 & & 0 & \\
\hline Cycloneda ocelligera & 0 & & 1 & $0.17 \%$ & 0 & \\
\hline Total & 539 & $99.98 \%$ & 586 & $99.99 \%$ & 1038 & $99.98 \%$ \\
\hline
\end{tabular}

R. cardinalis, H. festiva and C. ocelligera) were not collected after $H$. axyridis introduction. However, $C$. citricola was found for the first time in the 2006/2007 period and $O$. v-nigrum was more abundant after H. axyridis introduction. According to Dixon (2000) some species are more likely to meet and interact than others, because there might be an overlap of habitat preferences. Because C. citricola and O. v-nigrum feed on secondary food sources (coccids and psyllids), they may occupy different habitats on the plant when compared to $H$. axyridis, minimizing the dietary overlap.

In contrast, $H$. convergens explores the same food source as $\mathrm{H}$. axyridis, and its relative frequency changed from $20.59 \%$ in prior to the introduction to $0.48 \%$ after the introduction.

Before H. axyridis detection (1999/2000), the main species were: C. sanguinea $(58.07 \%)$, H. convergens $(20.59 \%)$ and Scymnus sp. (9.65\%); between 2001/2002, the abundance of C. sanguinea was $84.98 \%$ and H. axyridis $10.24 \%$; in 2006/ $2007, H$. axyridis dominated the Coccinellidae community with $91.23 \%$ and $C$. sanguinea with just $2.02 \%$ of the coccinellids collected.

The displacement of native Coccinellidae species after the introduction of $H$. axyrids has been already reported in the literature, particularly for $C$. sanguinea . In Argentina, Buenos Aires, the abundance of predatory species of the aphid Monellia caryella (Fitch, 1855) in pecan varied from 2001/ 2002 to $2003 / 2004$. H. axyridis ranged from $51 \%$ to $74 \%$ and the native $C$. sanguinea from $20 \%$ to $13 \%$, whereas $O$. v-nigrum, E. connexa, Coccinella quadrifasciata (Schoenherr, 1808) and Adalia bipunctata (Linnaeus, 1758) were less representative during all this period (Saini 2004).

In Brazil, Ponta Grossa, Paraná State, the relative frequencies of $H$. axyridis population in orchard trees (lemon, orange, apple, pear and peach trees) between two sampling periods were significantly different, varying from 0.20 to 0.67 , from one year to the other (Milléo et al. 2008).

A significant decrease in $C$. sanguinea relative abundance and an increase in H. axyridis also occurred in United States,
Florida (Michaud 2002). In Michigan the species Brachiacantha ursina (Fabricius, 1787), Cycloneda munda (Say, 1835) and Chilocorus stigma (Say, 1835), were apparently affected by the presence of $H$. axyridis (Colunga-Garcia \& Gage 1998).

It is possible to suggest explanations for the dominance of H. axyridis in the Coccinellidae guild and the displacement of ladybird species based on different authors and specific methodologies, such as the intraguild predation (IGP) (Cottrell 2005; Yasuda et al. 2001, Kajita et al. 2006), H. axyridis aggressiveness (Yasuda et al. 2001), and the competition for food (Evans 2000). Regarding the aggressiveness and IGP, in Japan, $80 \%$ of Coccinella septempunctata (L., 1758) larvae were eaten by $H$. axyridis fourth instar larvae, while the opposite rarely occurred (Yasuda et al. 2001). A. bipunctata was always the IGP prey and never a predator against $H$. axyridis, which significantly decreases its survival (Kajita et al. 2006).

Regarding the competition for food, the high aphid consumption of $H$. axyridis and consequently lower density of alimentary sources availability in an area has already been reported. The displacement of native species in alfalfa fields, in the United States, happened because the exotic species C. septempunctata consumed and consequently caused a reduction on the alimentary sources. Native species were forced to change their habitat to where there were more aphids available (Evans 2000). A substantial reduction on the abundance of aphid prey after the establishment of $H$. axyridis in potato crops Maine, United States was also noted (Alyokhin \& Sewell 2004).

It is currently known that biological invasions induce large impacts on the environment and are ecological threats in their new ecosystems (Pimentel et al. 2001). However, because Coccinellidae numbers varied considerably from year to year in a 12-years study at Blairstown, United States, long-term researches of at least 10 years are required to correctly identify population trends (Day \& Tatman 2006). 
Table IV. Number of Coccinellidae species sampled in Capão do Tigre, Curitiba, Paraná, Brazil. Period - October 2006 to September 2007.

\begin{tabular}{|c|c|c|c|c|c|c|c|c|c|c|c|c|c|c|}
\hline Species of Coccinellidae & Oct $/ 06$ & Nov & Dec & $\mathrm{Jan} / 07$ & Feb & Mar & Apr & Mai & Jun & Jul & Aug & Sep & Total & $\%$ \\
\hline Harmonia axyridis & 28 & 2 & 15 & 3 & 24 & 103 & 36 & 52 & 133 & 81 & 197 & 273 & 947 & 91.23 \\
\hline Hippodamia convergens & & & & 1 & 2 & & & & & & 1 & 1 & 5 & 0.48 \\
\hline Cycloneda sanguinea & & & & & 3 & 6 & 6 & 3 & 2 & & 1 & & 21 & 2.02 \\
\hline Olla v-nigrum & 3 & & & & 2 & & & 1 & & & 24 & 2 & 32 & 3.08 \\
\hline Cycloneda pulchella & 1 & & 1 & & & & & 1 & & & & & 3 & 0.29 \\
\hline Curinus coeruleus & 1 & & & & & & & & & & & & 1 & 0.10 \\
\hline Scymnus sp. & & & 3 & & & & & 7 & & & & & 10 & 0.96 \\
\hline Coccidophilus citricola & & & & & & & & 3 & 16 & & & & 19 & 1.83 \\
\hline Total & & & & & & & & & & & & & 1038 & $100 \%$ \\
\hline
\end{tabular}

The longest long-term study with a ladybird community has 31 years and was performed in northern Maine, United States (Alyokhin \& Sewell 2004). It revealed changes in the coccinellid community inhabiting potato crops. Before 1980, two native species Coccinella transversoguttata Fald, 1835, and Hippodamia tredecimpunctata (L. 1758) comprised the coccinellid communities, but in 1995 and 1996, exotic species H. axyridis and Propylea quatuordecimpunctata (L. 1758) became prominent members. Their invasion was followed by a significant decline in the abundance of native species and a significant increase in the overall diversity of ladybird community.

Besides negative impacts on native species, other effects, caused by $H$. axyridis, are discussed by some authors, especially in the United States. Recently in Minnesota, H. axyridis was seen eating damaged fruits, like pumpkins, apples, grapes, and raspberries (Koch et al. 2004). In vineyards H. axyridis gathers in clusters of grapes causing issues in wine production, altering its flavor with the presence of alkaloids (Pickering $e t$ al. 2004). In colder periods, $H$. axyridis invades households searching for shelter and also may be found on food and beverages (Knodel \& Hoebeke 1996). In some people, the direct contact with the insects triggers allergic reactions, provoking symptoms, such as rhinitis, conjunctivitis, chronic cough and asthma (Yarbrough et al. 1999).

Features considered advantageous in biological control such as the capacity for self replication, the fast population increase, and the high dispersion, raise the likelihood of unexpected ecological effects. After the exotic species proliferation, a pressure to control them emerges, stimulating the need to understand biological control and ecological effects, and also a need for a scientific monitoring in order to measure and foresee possible impacts (Louda et al. 2003). Considering $H$. axyridis, there is no available method to diminish its population densities and restrict its impacts over native coccinellids (Kenis et al. 2008).

In Brazil, H. axyridis was sampled for the first time in 2002 in the city of Curitiba. A survey revealed at least 20 aphid species used as alimentary sources. In 2009, seven years after its introduction, $H$. axyridis is already present in the city of Brasilia, more than $1,000 \mathrm{~km}$ far from Curitiba indicating a high dispersal capability. In Capão do Tigre area, $H$. axyridis dominates the Coccinellidae community summing up to $90 \%$ of the species sampled. The most abundant species of the area in 1999/2000, C. sanguinea and $H$. convergens, were strongly affected by the presence of $H$. axyridis, summing in 2006/2007 less than 3\% of the Coccinellidae community. Considering this scenario, future studies should focus on $H$. axyridis sampling methods and monitoring, and on experimental investigations on the interaction between $H$. axyrids and native Coccinellidae species, because little is known about the ecological roles of $H$. axyridis and its potential to compete and displace native Coccinellidae species in South America.

Acknowledgements. We are thankful to Dr. Mauricio Osvaldo Moura, from Universidade Estadual do Centro-Oeste, Paraná and the reviewers for critically reviewing and improving the draft of the manuscript; to Dr. Renato Goldenberg and to the graduate student Marcelo Reginatto, from the Botanical Department of UFPR for the identification of plants. We are also indebted to Venicio Borges da Silva for providing data from the period of 1999 to 2002.

\section{REFERENCES}

Adriaens, T.; E. Branquart \& D. Maes. 2003. The Multicolored Asian Ladybird Harmonia axyridis Pallas (Coleoptera: Coccinellidae), a threat for native aphid predators in Belgium? Belgium Journal of Zoology 133: 195-196.

Almeida, L. M \& V. B. Silva. 2002. Primeiro registro de Harmonia axyridis (Pallas) (Coleoptera, Coccinellidae): um coccinelídeo originário da região Paleártica. Revista Brasileira de Zoologia 19: $941-944$

Alyokhin, A. \& G. Sewell. 2004. Changes in a lady beetle community following the establishment of three alien species. Biological Invasions 6: 463-471.

Arioli, M. C. S. \& D. Link. 1987. Ocorrência de joaninhas em pomares cítricos na região de Santa Maria, RS. Revista Centro de Ciências Rurais 17: 213-222.

Berkvens, N.; J. Bonte; D. Berkvens; K. Deforce; L. Tirry \& P. De Clercq. 2008. Pollen as an alternative food for Harmonia axyridis. BioControl 53: 201-210.

Brown, M. W. \& S. S. Miller. 1998. Coccinellidae (Coleoptera) in apple orchards of eastern West Virginia and the impact of invasion by Harmonia axyridis. Entomological News 109: 136-142.

Brown, P. M. J.; T. Adriaens; H. Bathon; J. Cuppen; A. Goldarazena; T. Hägg; M. Kenis; B. E. M. Klausnitzer; I. Kováø; A. J. M. Loomans; M. E. N. Majerus; O. Nedved; J. Pedersen; W. Rabitsch; H. E. Roy; V. Ternois; I. A. Zakharov \& D. B. Roy. 2008. Harmonia axyridis in Europe: spread and distribution of a non-native coccinellid. BioControl 53: 5-21.

Cardoso, J. T. \& S. M. N. Lazzari. 2003. Consumption of Cinara spp. (Hemiptera, Aphididae) by Cycloneda sanguinea (Linnaeus, 1763) and Hippodamia convergens Guérin-Méneville, 1842 (Coleoptera, Coccinellidae). Revista Brasileira de Entomologia 47: 559-562. 
Chapin, J. B. \& V. A. Brou. 1991. Harmonia axyridis (Pallas), the third species of the genus to be found in the United States (Coleoptera: Coccinellidae). Proceedings of the Entomological Society of Washington 93: 630-635.

Colunga-Garcia, M. \& S. Gage. 1998. Arrival, establishment, and habitat use of the multicolored Asian ladybeetle (Coleoptera: Coccinellidae) in a Michigan landscape. Environmental Entomology 27: 15741580 .

Cottrell, T. E. 2005. Predation and cannibalism of lady beetle eggs by adult lady beetles. Biological Control 34: 159-164.

Day, W. H. \& K. M. Tatman. 2006. Changes in abundance of native and adventives Coccinellidae (Coleoptera) in alfafa fields, in northern New Jersey (1993-2004) and Delaware (1999-2004), U.S.A. Entomological News 117: 491-502.

Dixon, A. F. G. 2000. Insect predator - prey dynamics. Ladybirds Beetles \& Biological Control. Cambridge University Press. Cambridge. 257 p.

Elliot, N.; R. Kieckhefer \& W. Kauffman. 1996. Effects of an invading coccinellid on native coccinellids in an agricultural landscape. Oecologia 105: 537-544.

Evans, E. W. 2000. Habitat displacement of North American ladybirds by an introduced species. Ecology 85: 637-647.

Ganho, N. G. \& R. C. Marinoni. 2005. A diversidade inventarial de Coleoptera (Insecta) em uma paisagem antropizada do Bioma Araucária. Revista Brasileira de Entomologia 49: 535-543.

González, G. 2006. Los Coccinellidae de Chile. Available at: <http:/ /www.coccinellidae.cl>. Access 07/12/2007.

González, G. \& N. Vandenberg. 2007. Los Coccinellidae de Perú. $<$ http://www.coccinellidae.cl/paginasWebPeru>. Access 07/12/2007.

Gordon, R. D. 1985. The Coccinellidae (Coleoptera) of America north of Mexico. Journal of New York Entomology Society 93: 1912.

Hironori, Y. \& S. Katsuhiro. 1997. Cannibalism and interspecific predation in two predatory ladybirds in relation to prey abundance in the field. Entomophaga 42: 153-163.

Hodek, I. \& A. Honek. 1996. Ecology of Coccinellidae. Kluwer Academic Publishers. Dordrecht. 464 p.

Kajita, Y.; T. Fumiyo; Y. Hironori \& E. W. Evans. 2006. Interactions between introduced and native predatory ladybirds (Coleoptera, Coccinellidae): factors influencing the success of species introductions. Ecological Entomology 31: 56-67.

Katsoyannos, P.; D. C. Kontodimas; G. J. Stathas \& C. T. Tsartsalis. 1997. Establishment of Harmonia axyridis on citrus and some data on its phenology in Greece. Phytoparasitica 25: 183-191.

Kenis, M.; H. E. Roy; R. Zindel \& M. E. N. Majerus. 2008. Current and potential management strategies against Harmonia axyridis. BioControl 53: 235-252.

Kingler, J.; G. Powell; G. A. Thompson \& R. Isaacs. 1998. Phloem specific aphid resistance in Cucumis melo line AR5 effects on feeding behaviour and performance of Aphis gossypii. Entomologia Experimentalis et Applicata 86: 79-88.

Knodel, J. J. \& R. E. Hoebeke. 1996. Multicolored Asian Lady Beetle, Harmonia axyridis (Pallas), Coleoptera: Coccinellidae. Cornell University. <http:// www.nysaes.cornell.edu/ent/biocontrol/predators/harmonia.html>. Access 13/06/2007.

Koch, R. L. 2003. The multicolored Asian beetle, Harmonia axyridis: A review of its biology, uses in biological control, and non-target impacts. Journal of Insects Science 32: 1-16.

Koch, R. L.; W. D. Hutchison; R. C. Venette \& G. E. Heimpel. 2003. Susceptibility of immature monarch butterfly, Danaus plexippus (Lepidoptera: Nymphalidae: Danainae), to predation by Harmonia axyridis (Coleoptera: Coccinellidae). Biological Control 28: 265270

Koch, R. L.; E. C. Burkness; S, J. Burkness \& W. D. Hutchison. 2004. Phytophagous Preferences of the Multicolored Asian Lady Beetle (Coleoptera, Coccinellidae) for Autumn-Ripening Fruit. Journal of Economic Entomology 97: 539-544.

Koch, R. L.; R. C. Venette \& W. D. Hutchinson. 2006. Invasions by Harmonia axyridis (Pallas) (Coleoptera, Coccinellidae) in the
Western Hemisphere: Implications for South America. Neotropical Entomology 35: 421-434.

Koch, R. L. \& T. L. Galvan. 2008. Bad side of a good beetle: the North American experience with Harmonia axyridis. BioControl 53: 23-35.

Köppen, W. 1948. Climatologia: con un studio de los climas de la tierra. Fondo de Cultura Econômica. México. 479 p.

LaMana, M. L \& J. C. Miller. 1996. Field observations on Harmonia axyridis Pallas (Coleoptera: Coccinellidae) in Oregon. Biological Control 6: 232-237.

Leite, G. L. D.; M. Picanço; J. C. Zanuncio \& M. R. Gusmão, 2007 Factors affecting colonization and abundance of Aphis gossypii Glover (Hemiptera, Aphididae) on okra plantations. Ciência e Agrotecnologia 31: 337-343.

Louda, S. M.; R. W. Pemberton; M. T. Johnson \& P. A. Follett. 2003 Nontarget effects: The Achille's Heel of biological control? Retrospective Analyses to Reduce Risk Associated with Biocontrol Introductions. Annual Review of Entomology 48: 365-396.

Lucas, E.; D. Coderre \& C. Vincent. 1997. Voracity and feeding preferences of two aphidophagous coccinellids on Aphis citricola and Tetranychus urticae. Entomologia Experimentalis et Applicata 85: 151-159.

Maack, R. 1981. Geografia Física do Paraná. 2ed. Rio de Janeiro: J. Olympio. Secretaria da Cultura e do Esporte do Governo do Estado do Paraná. $450 \mathrm{p}$.

McClure, M. S. 1986. Role of predators in regulation of endemic populations of Matsucoccus matsumarae (Homoptera: Margarodidae) in Japan. Environmental Entomology 15: 976 983.

Michaud, J. P. 2004. Natural mortality of Asian citrus psyllid (Homoptera: Psyllidae) in Central Florida. Biological Control 29: 260-269.

Michaud, J. P. 2002. Invasion of the Florida Citrus Ecosystem by Harmonia axyridis (Coleoptera: Coccinellidae) and Asymmetric Competition with a Native Species, Cycloneda sanguinea. Environmental Entomology 31: 827-835.

Milléo, J.; J. M. T. Souza; I. F. Barbola \& P. E. Husch. 2008. Harmonia axyridis em árvores frutíferas e impacto sobre outros coccinelídeos predadores. Pesquisa Agropecuária Brasileira 43: 537-540.

Musser, F. R. \& A. M. Shelton. 2003. Bt sweet corn and selective insecticides: impacts on pests and predators. Journal of Economic Entomology 96: 71-80.

Neupane, F. P.; M. D. Sharma \& K. R. Neupane. 2006. Incidence of Insect Pests on Chayote, Sechium edule (Swartz.) in Nepal. Journal of the Institute of Agriculture and Animal Science 27: 161164.

Ongagna, P.; L. Giuge; G. Iperti \& A. Ferran. 1993. Cycle de development d'harmonia axyridis (Col. Coccinellidae) dans son aire d'introduction le sud-est de la france. Entomophaga 38: 125128.

Osawa, N. 1993. Population field studies of the aphidophagous ladybird beetle Harmonia axyridis (Coleoptera: Coccinellidae): life tables and key factor analysis. Researches on Population Ecology 35: $335-348$.

Osawa, N. 2000. Population field studies on the aphidophagous ladybird beetle Harmonia axyridis (Coleoptera, Coccinellidae): resource tracking and population characteristics. Population Ecology 42: $115-127$.

Peronti, A. L. B. G. \& C. R. Souza-Silva. 2002. Aphids (Hemiptera: Aphidoidea) of ornamental plants from São Carlos, São Paulo state, Brazil. Revista de Biología Tropical 50: 137-144.

Pickering G. J.; J. Lin; R. Riesen; A. Reynolds; I. Brindle \& G. Soleas 2004. Influence of Harmonia axyridis on the sensory properties of white and red wine. American Journal of Enology and Viticulture 55: 153-159.

Pimentel, D.; S. McNair; J. Janecka; J. Wightman; C. Simmonds; C. O'Connell; E. Wong; L. Russel; J. Zern; T. Aquino \& T. Tsomondo. 2001. Economic and environmental threats of alien plant, animal, and microbe invasions. Agriculture, Ecosystems, and Environment 84: 1-20. 
Poutsma, J.; A. J. M. Loomans; B. Aukema \& T. Heijerman. 2008. Predicting the potential geographical distribution of the harlequin ladybird, Harmonia axyridis, using the Climex model. BioControl 53: $103-125$.

Saini, E. D. 2004. Presencia de Harmonia axyridis (Pallas) (Coleoptera: Coccinellidae) en la provincia de Buenos Aires. Aspectos Biológicos y Morfológicos. Revista de Investigaciones Agropecuarias 33: $151-160$.

StatSoft, Inc. 2000. Statistica for Windows. Tulsa: Statsoft.

Steenis, M. J. van \& K. A. M. H. El-Khawass. 1995. Life history of Aphis gossypiion cucumber: influence of temperature, host plant and parasitism. Entomologia Experimentalis et Applicata 76: $21-131$.

Stuart, R. J.; J. P. Michaud; L. Olsen \& C. W. McCoy. 2002. Lady beetles as potential predators of the root weevil Diaprepes abbreviatus (Coleoptera: Curculionidae) in Florida citrus. Florida Entomologist 85: 409-416.

Tan, C. C. 1946. Mosaic dominance in the inheritance of color patterns in the ladybird beetle, Harmonia axyridis. Genetics 31: 195-210.

Wang, J. \& J. H. Tsai. 2000. Effect of temperature on the biology of Aphis spiraecola (Homoptera: Aphididae). Annals of the Entomological Society of America 93: 874-883.

Yarbrough, J. A.; J. L. Armstrong; M. Z. Blumberg; A. E. Philips; E. Mcgahee \& W. K. Dolen. 1999. Allergic rhinoconjunctivitis caused by Harmonia axyridis (Asian lady beetle, Japanese lady beetle or lady bug). Journal of Allergy and Clinical Immunology 104: 704-705.

Yasuda, H.; T. Kikuchi; P. Kindlmann \& S. Sato. 2001. Relationship between attack and escape rates, cannibalism, and intraguild predation in larvae of two predatory ladybirds. Journal of Insect Behavior 14: 373-384. 